\section{Boas práticas no tratamento do uso e dependência de substâncias}

Cordeiro D, Figlie N, Laranjeira R. Editora Roca; 2007. 248 p. ISBN: 978-85-7241-712-9

Este livro nos é apresentado como o produto de uma jornada científica na qual o trabalho terapêutico de 13 anos da Unidade de Pesquisa em Álcool e Drogas (UNIAD) com dependentes químicos é exposto. A pretensão dos autores é passar ao leitor uma síntese das evidências científicas depuradas pelo trabalho clínico conduzido no mundo real. Nesta medida, apresenta-se como um manual de leitura fácil, com conteúdo atual e consistente.

Os autores destacam suas propostas sobre o uso nocivo e a dependência de álcool, cocaína e maconha discutindo, com densidade, a abordagem inicial, a entrevista motivacional, o uso dos diferentes fármacos para as diferentes fases do tratamento, bem como as múltiplas formas psicoterápicas e suas indicações, notadamente a prevenção da recaída, a psicoterapia cognitivocomportamental e o treinamento de habilidades psicossociais. Também as terapias de família e um tipo de grupo de auto-ajuda são abordados.

0 destaque principal é que não existe um tratamento útil para todos os pacientes e nem um serviço capaz de atender todas as necessidades, o que conduz o leitor à idéia de "gerenciamento de caso", imposição contemporânea na abordagem terapêutica dos dependentes químicos e seus familiares.

Por estes predicados, Boas práticas no tratamento do uso e dependência de substâncias torna-se leitura obrigatória para tantos quantos queiram trabalhar nesta área e preenche uma lacuna existente no mercado editorial. Como, por estes motivos, prevê-se para logo uma segunda edição, penso que os autores poderiam considerar os comentários seguintes.

No título do livro, "tratamento do uso", que foi o resultado de uma simplificação, escorrega para o impróprio, pois uso não é um agravo à saúde e, portanto, não se indica tratamento. No caso das drogas ilícitas, pode ser mesmo um crime, mas o território dos profissionais da saúde começa no uso nocivo, costumeiramente condensado como abuso.

A escolha de álcool, cocaína e maconha foi ditada pela epidemiologia, mas, esta considerada, restou injustificada a omissão do tabaco, de longe a mais prevalente dependência química no Brasil.

Como as técnicas psicoterápicas são as mesmas para todas as dependências, os autores poderiam reestruturar o livro, com o escopo de não cansar o leitor com repetições desnecessárias, em duas partes onde, na primeira, poderiam explicitar o que fazem de comum para todos os tipos de dependências, reservando para a segunda as especificidades. Ou seja, entrevista motivacional é a mesma tanto para alcoolistas quanto para craqueiros. Isso considerado, é minha opinião que a leitura seria mais agradável.

Outro ponto a considerar é a verdadeira alquimia necessária para bem mesclar a literatura científica com a experiência clínica. Sobre a primeira, os autores demonstram forte preferência pelos de língua inglesa e, quando referenciam os nacionais, apresentam uma inclinação a apenas citarem-se mutuamente, desconsiderando mais de 40 anos de produção dos patrícios. Quanto à experiência clínica, nota-se a conveniência de um melhor trabalho editorial, pois é visível que os menos experientes tendem a exagerar nas

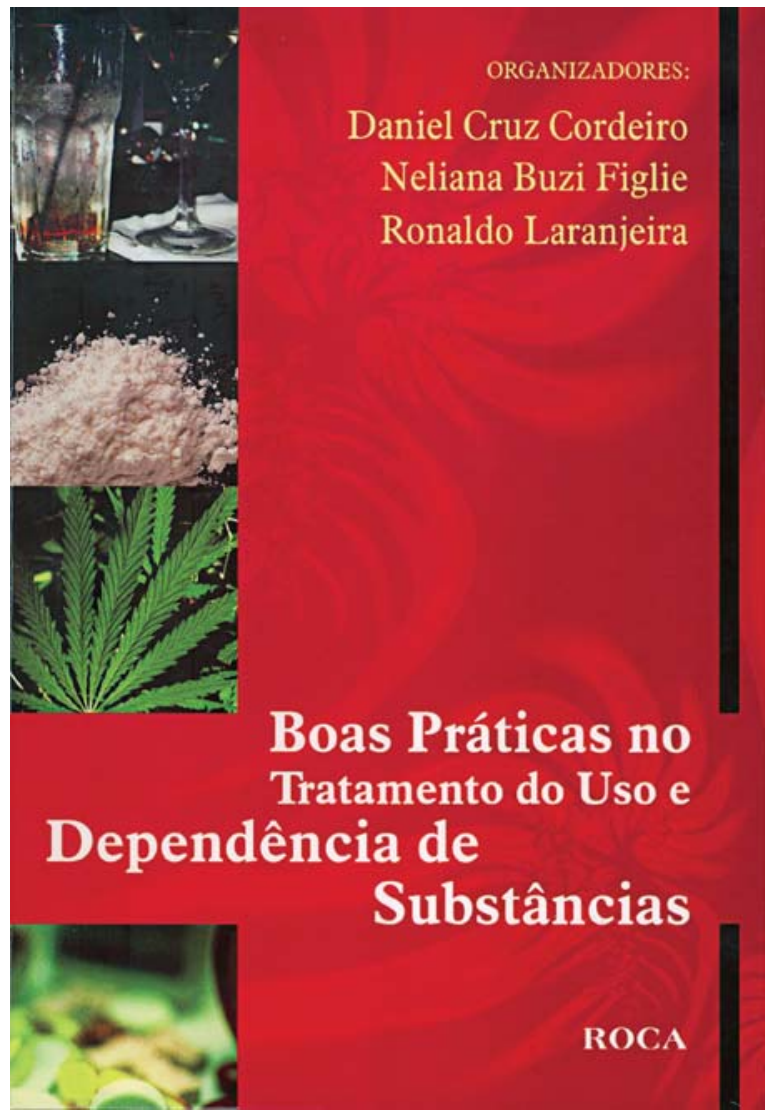

citações e os anunciados "segredos" no manejo terapêutico são sumariamente omitidos.

O último comentário denuncia a omissão dos demais grupos de auto-ajuda. Ainda que relevante o trabalho do "Amor Exigente" para jovens envolvidos com drogas, nem de longe se aproxima da importância dos AA - e há espaço para todos.

Por fim, trata-se de importante contribuição, cuja leitura recomendo. No entanto, como qualquer livro científico/clínico, pode ser melhorado no futuro.

Sérgio de Paula Ramos Unidade de Dependência Química, Hospital Mãe de Deus, Porto Alegre (RS), Brasil 